\title{
V. Description and analysis of the meteoric stone which fell at Weston, in North America, the 4th December 1807
}

\section{David Bailie Warden Esq.}

To cite this article: David Bailie Warden Esq. (1810) V. Description and analysis of the meteoric stone which fell at Weston, in North America, the 4th December 1807, Philosophical Magazine Series 1, 36:147, 32-34, DOI: 10.1080/14786441008563133

To link to this article: http://dx.doi.org/10.1080/14786441008563133

Published online: 18 May 2009.

Submit your article to this journal $\pi$

Џll Article views: 2

View related articles 
to the manufacture of nitrous acid. And there is reason to believe that the ignition of charcoal and potash, and their exposure to water, may be advantageously applied to the production of volatile alkali, in countries where fuel is cheap.

[To be continued.]

V. Description and Analysis of the Meteoric Stone which fell at Weston, in North America, the 4th December 1807. By David Bailie Warden, Esq. Consulgeneral of the United States at Paris*.

\section{Description.}

This aerolite presents, in general, the same characters as those hitherto examined. It is enveloped with a thin, black, and uneven crust. The mass is principally composed of a granular substance, which breaks easily; it has an earthy appearance and a gray cinereous colour, which, in certain parts, passes to a whitish gray.

Those portions which possess this last tint, and which are as if glued in the mass, have a round form, so that they are distinguished by circular or oval spots which interrupt the general colour. Its specific gravity is about 3.3 : the sharp parts cut glass.

In observing the fractured parts of the stone, we there perceive : $1^{\circ}$. Particular globules which are easily detached; little cells in which they are placed, and of which the substance is like that of the stone itself, except that its grain. is more compact, and its fracture smoother.

In exposing it to a strong light, we see traces of a lamellar tissue : $2^{\circ}$. grains of metallic iron, which, by polish, assume a whiteness, $y$ ield to the hammer, and attract very sensibly the magnetic neerle: $3^{\circ}$. grains of oxided iron of the colour of rust : $4^{\circ}$. metallic particles extremely small, of a silver white colour, which seem to be of iron; and this opinion is strengthened, when we recollect that the native iron of Kamerdorf, and that of pseudo-volcanic origin, present, in certain parts, a silver white colour.

I have not seen any mark of sulphîrated iron, although I found it by the analysis, as will hereafter appear.

All the fragments of this stone have a magnetic property, but without polarity; and the iron, which is very visible in certain parts, is so disseminated in all others where it escapes the eye, that the property of which there is ques-

* From Annales de Chimie of March 1810. 
tion, manifests itself even in the smallest particles isolated by trituration.

I found it even in the globulous bodies which are first mentioned.

Pieces of this stone weighed from six to even 100 pounds.

ANALYSIS.

Having ascertained, by preliminary essays, that this stone contained chrome, nickel, iron, manganese, lime, magnesia, silex, alumine, and sulphur; I employed the following method of separating each of these substances.

$1^{\circ}$. 100 grains of this stone, from which the metallic iron was isolated, by means of the magnetic needle, after being pulverised, were treated with a considerable quantity of water, through which was passed a current of oxygenated muriatic gas : by this means, the sulphur being converted into sulphuric acid, by the oxygen of the oxygenated muriatic acid, sulphates and muriates were obtained.

$2^{\circ}$. The whole was evaporated to siccity, and treated with two parts of alcoholic potash : after fusion the mass presented a fallow colour, and its dissolution in water was of a fine yellow.

$3^{\circ}$. The portions of the mass, which remained undissolved in water, were dissolved in an excess of muriatic acid; and being evaporated to siccity, I separated the silex, which after calcination weighed 4: grains.

$4^{\circ}$. Into the muriatic acid was poured carbonate of potash in excess, which formed an abundant precipitate after an hour of ebullition.

$5^{\circ}$. The liquor contained sulphate and chromate of potash: after being made acid, it was precipitated by muriate of barytes in excess, and there was obtained sulphate of barytes, corresponding to $2+$ of sulphur : and saturating afterwards the excess of acid by an alkali, 1 obtained chromate of barytes, corresponding to $2 \frac{1}{3}$ of chromic acid.

$6^{\circ}$. The precipitate, No.4, was submitted (still in a humid state) to the action of alconolic potash, and after filtration, the liquor gave, by means of the muriate of ammonia, a grain of alumine.

$7^{\circ}$. Ammonia was poured into the remains of the precipitate, after having dissolved it in an excess of muriftic acid. The oxides of iron and manganese were precipitated, and the lime and magnesia remained in dissolution.

$8^{\circ}$. The precipitate was isolated, and the lime separated from the magnesia by the oxalate of ammonia, which, after calcination, weighed three grains.

Vol. 36. No, 147. July 1810. The 
The magnesia was precipitated by caustic potash : it weighed, after desiccation, 16 grains.

$9^{\circ}$. The oxides of iron and manganese were dissolved in an excess of muriatic acid, and pouring, by little and little, saturated carbonate of potash into the dissolution until red floccules were visible, and then leaving it to repose 24 hours, all the carbonate of iron precipitated, whilst that of the manganese remained in the liquor.

The cartonate of iron, after calcination, gave 24 grains of oxide : and that of manganese, deposited by ebullition, by the same operation, only $1 \frac{1}{3}$-Which makes in all :-

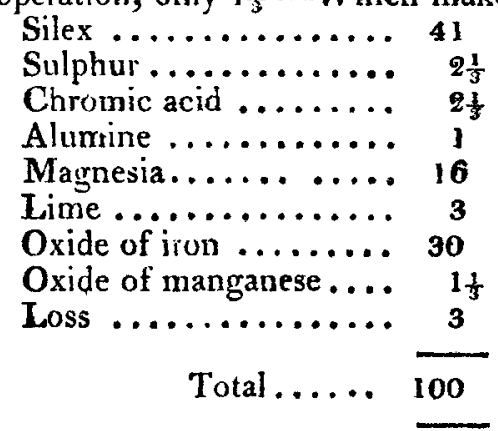

Analysis of the metallic iron isolated by the magnetic needle. $1^{\circ}$. 100 parts of this stone gave 28 of 'metallic iron, which is very brittle, owing to the nickel it contains. $2^{\circ}$. 40 grains of this iron were dissolved in nitro-muriatic acid, and by means of ammonia in excess the oxide of iron was separated, which weighed 45 grains. The dissolution of nickel in this alkali was evaporated to siccity to expell all the ammonia. The oxide of nickel was redissolved by muriatic acid, and precipitated by the prussiate of potash, which gave one grain of the prussiate of nickel. We may infer, from these physical characters, and results of chemical analysis, that this stone is like all other meteoric stones hitherto known.

V. Propasal for constructing, and putting in its Place, an Iron Tunnel under the River Thames. By Colonet Lennox.

To Mr. Tilloch.

SIR, I nerkwith send you a plan for a tunnel under the Thames, which I hope you will not deem unworthy of a place in your valuable Magazine. 